TRANSACTIONS

OF THE

ROYAL HISTORICAL SOCIETY 
The Society, AS A BODY, is not responsible for the opinions advanced in the following pages. 


\title{
T RANSACTIONS
}

\author{
OF THE
}

Royal Historical Society

\section{fourtb Series}

Volume XII

\section{LONDON \\ OFFICES OF THE SOCIETY}

22 RUSSELL SQUARE, W.C.I

Ig29 
Made and Printed in Great Britain by Butler \& Tanner Ltd., Frome and London 


\section{CONTENTS}

Address by the President: "History and Historians in America." By Professor T. F. Tout, D.Litt., LL.D., F.B.A

The Transformation of the Keepers of the Peace into the Justices of the Peace, I327-I380. By Professor Bertha Haven Putnam, Ph.D., F.R.Hist.S. . . .

The Administration of the Diocese of Ely During the VACANCIES OF THE SEE, I 298-9 AND I 302-3. By Dr. Rose Graham, D.Litt., F.S.A., F.R.Hist.S.

The System of Account in the Wardrobe of Edward II. By J.H.Johnson, M.A., F.R.Hist.S.

The Imprisonment of the Earl of Danby in the Tower (I679-1684). From Papers at Hornby Castle. By Miss A. M. Evans, M.A., F.R.Hist.S. . . . . . 105

The Relations of William III with the Swiss Protestants, 1689-1697. By L.A.Robertson, M.A., B.Litt., F.R.Hist.S.

Lord Palmerston's Policy for the Rejuvenation of TuRkey, I839-184I. By Professor F. S. Rodkey, Ph.D. The Alexander Prize Essay, I929 . . . . I63

INDEX $\quad \cdot \quad \cdot \quad \cdot \quad \cdot \quad \cdot \quad \cdot \quad \cdot \quad \cdot \quad \cdot \quad \cdot \quad r 93$

REPORT OF COUNCIL

List of Fellows . . . . . . . . . . 2I3 